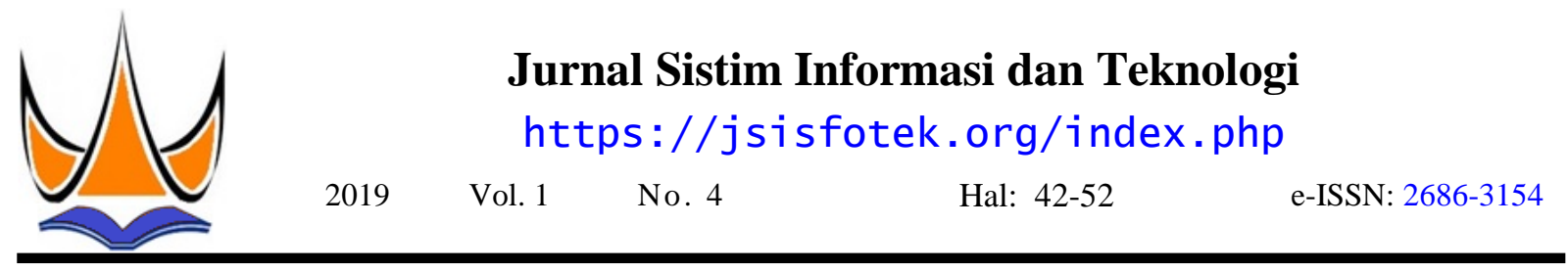

\title{
Diagnosis Penyakit Diabetes pada Masyarakat Awam Menggunakan Metode Backward Chaining
}

\author{
Don Luthvan ${ }^{凶}$ \\ Magister Teknik Komputer, Ilmu Komputer, Universitas Putra Indonesia "YPTK” Padang \\ don1uthvan9@gmai1.com
}

\begin{abstract}
Expert system is a system that seeks to adopt human knowledge into computers, this research was conducted to diagnose diabetes early. Disease data that were processed were sourced from the South Solok District General Hospital. The method used is Backward Chaining by using a goal-driven approach. The result of testing this method is that the user understands the danger of diabetes and knows how to prevent it. Trials conducted on an expert system for diagnosing diabetes, most people understand the characteristics and symptoms of diabetes and understand how to prevent it. So that this expert system can be recommended for ordinary people.
\end{abstract}

Keywords: Diabetes, Backward chain, PHP, MySQL, Expert System.

\begin{abstract}
Abstrak
Sistem pakar adalah sistem yang berupaya mengadopsi pengetahuan manusia ke dalam komputer, penelitian ini dilakukan untuk mendiagnosis diabetes sejak dini. Data penyakit yang diproses bersumber dari Rumah Sakit Umum Kabupaten Solok Selatan. Metode yang digunakan adalah Backward Chaining dengan menggunakan pendekatan goal-driven. Hasil dari pengujian metode ini adalah bahwa pengguna memahami bahaya diabetes dan tahu bagaimana cara mencegahnya. Uji coba dilakukan pada sistem pakar untuk mendiagnosis diabetes, kebanyakan orang memahami karakteristik dan gejala diabetes serta memahami cara mencegahnya. Sehingga sistem pakar ini bisa direkomendasikan untuk orang awam.
\end{abstract}

Kata kunci: Diabetes, Backward Chaining. PHP, MySQL, Sistem Pakar.

(C) 2019 Jurnal SISFOTEK

\section{Pendahuluan}

Sistem Pakar pertama kali dikembangkan pada tahun 1960 dan 1970 dan diterapkan secara komersial pada Dengan kata lain, prosesnya dimulai dari initial tahun 1980. Sistem Pakar banyak digunakan untuk hyphotesis or goal (Hipotesa awal atau tujuan) melalui membantu pengguna guna mengambil keputusan dalam intermediete hipothesis or sub goals (hipotesa lanjutan salah satu bidang tertentu misalnya dibidang kesehatan, atau bagian dari tujuan) yang akan memeriksa semua dimana pasien/user yang jaraknya jauh dari pusat hipotesa yang ada apakah hipotesa itu benar atau salah layanan kesehatan bisa menggunakan Sistem Pakar ini sehingga akhirnya akan menuju suatu Evidence (fakta). untuk mengetahui gejala awal penyakit. Sehingga pasien/user bisa melakukan pertolongan awal menjelang mengunjungi ke pusat layanan kesehatan. Ada beberapa metode yang digunakan dalam penggunaan Sistem Pakar salah satunya adalah metode Backward Chaining.

Backward Chaining adalah Penalaran berdasarkan lanana pasien/user yang jaraknya jauh dari pusat tujuan (goal-driven), metode ini dimulai dengan untuk mengetahui gejala awal penyakit. Sehingga membuat perkiraan dari apa yang akan terjadi, pasien/user bisa melakukan pertolongan awal kemudian mencari fakta-fakta (evidence) yang menjelang mengunjungi ke pusat layanan kesehatan. mendukung (atau membantah) hipotesa tersebut. Ada beberapa metode yang digunakan dalam Backward chaining adalah suatu alasan yang penggunaan Sistem Pakar salah satunya adalah metode berkebalikan dengan hypothesis, potensial konklusinya Backward Chaining. 
Backward Chaining adalah Penalaran berdasarkan melakukan konseling tanpa memikirkan kapan guru BK tujuan (goal-driven), metode ini dimulai dengan hadir [5].

membuat perkiraan dari apa yang akan terjadi, kemudian mencari fakta-fakta (evidence) yang mendukung (atau membantah) hipotesa tersebut. Backward chaining adalah suatu alasan yang berkebalikan dengan hypothesis, potensial konklusinya mungkin akan terjadi atau terbukti, karena adanya fakta yang mendukung akan hypothesis tersebut.

Di Arab Saudi Sistem Pakar juga digunakan untuk diagnosis penyakit psikologis. Dengan menggunakan metode Backward Chaining serta data-data penyakit psikologis serta gejala-gejalanya terdahulu, maka pengguna bisa melakukan konsultasi online dengan memasukkan gejala penyakit yang diderita. Hasilnya pengguna bisa mengetahui penyakit apa yang diderita Dengan kata lain, prosesnya dimulai dari initial dan apa yang harus dilakukan [6]. hyphotesis or goal (Hipotesa awal atau tujuan) melalui intermediete hipothesis or sub goals (hipotesa lanjutan atau bagian dari tujuan) yang akan memeriksa semua hipotesa yang ada apakah hipotesa itu benar atau salah sehingga akhirnya akan menuju suatu Evidence (fakta).

Metode Backward Chaining ini bisa digunakan juga di penderita diabetes dari tahun ke tahun menunjukan bidang kesehatan seperti menentukan nutrisi yang tepat peningkatan yang tinggi.

bagi ibu hamil. Dimana Sistem Pakar dapat mendiagnosis dan Menentukan nutrisi yang tepat bagi ibu hamil serta memberikan rekomendasi yang tepat Sistem Pakar adalah sistem komputer yang ditujukan bagi ibu hamil. Dengan menggunakan data-data untuk meniru semua aspek (emulates) kemampuan sebelumnya sehingga Hasil penerapan metode ini pengambilan keputusan (decision making) seorang adalah ibu hamil mengetahui nutrisi apa yang tepat pakar. Sistem Pakar memanfaatkan secara maksimal digunakan saat hamil serta memberikan solusi yang pengetahuan khusus selayaknya seorang pakar untuk tepat dengan gejala yang dipilih [1]. memecahkan masalah.

Penerapan metode Backward Chaining lainnya di Pakar atau ahli (expert) didefinisikan sebagai seseorang dalam kesehatan adalah pemilihan menu makanan yang memiliki pengetahuan atau keahlian khusus yang berdasarkan penyakit dan golongan darah. Dimana tidak dimiliki oleh kebanyakan orang. Seorang pakar pengguna terbantu untuk mengetahui menu makanan dapat memecahkan masalah yang tidak mampu yang bermanfaat dan baik dikonsumsi sesuai dengan dipecahkan kebanyakan orang. Dengan kata lain, dapat penyakit dan golongan darah dengan menggunakan memecahkan suatu masalah dengan lebih efisien metode Backward Chaining [2].

Selain itu Sistem Pakar ini juga membantu orang tua untuk mengambil keputusan terhadap tingkat kecanduan game pada anak. Dengan menggunakan metode Backward Chaining ini dan dibantu dengan data-data yang tersedia seperti data jenis perilaku kecanduan game dan data gejala-gejala perilaku kecanduan game. Hasilnya adalah orang tua mengetahui tingkat kecanduan anak terhadap game serta memberikan rekomendasi [3].

Sistem Pakar tidak hanya tersedia di PC maupun Laptop tetapi tersedia di smartphone. Contohnya adalah pemilihan alat kontrasepsi yang cocok berbasis android, jadi pengguna bisa melakukan konsultasi dan hasil didapatkan adalah informasi dan rekomendasi alat kontrasepsi yang terbaik. Pengguna bisa melakukan konsultasi dimanapun pengguna berada hanya menggunakan smartphone saja [4]

namun bukan berarti lebih murah. Pengetahuan yang dimuat ke dalam sisitem pakar dapar berasal dari seorang pakar atau pun pengentahuan yang berasal dari buku, jurnal, majalah dan didomentasi yang dipublikasikan lainnya, serta orang yang memiliki pengetahuan meskipun bukan ahli. Istilah sistem pakar (Expert System). Sering disinonimkan dengan sistem berbasis pengetahuan (knowledge-based system) atau sistem pakar berbasis pengetahuan (knowledge-based expert system).

User memberikan informasi atau fakta kepada sistem dan menerima respon berupa saran ahli (advice/expertise). Secara internal, sistem terdiri dari dua komponen utama yaitu basis pengetahuan (knowledege based), berisi pengetahuan yang akan digunakan oleh komponen lainnya yaitu mesin onferensi (inference engine) untuk maneghasilkan kesimpulan sebagai respon terhadap kueri yang dilakukan user. Gambar 1 dibawah ini mengilustrasikan Contoh lain penggunaan Sitem Pakar adalah Pusat konsep dasar sistem pakar berbasis pengetahuan Informasi Konseling Remaja di SMAN 2 Dumai. (knowledge based expert system).

Dengan menggunakan Backward Chaining, siswa bisa melakukan konseling dimana saja dan kapan saja. Data yang di ambil dengan melakukan wawancara langsung terhadap siswa sehingga mempermudah dalam 


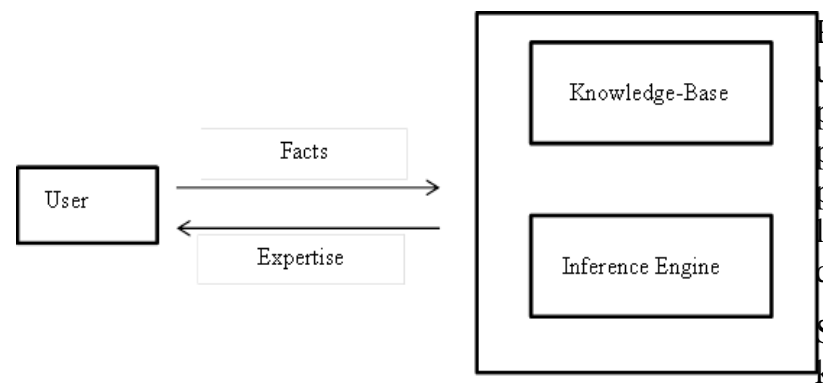

Pada umumnya, antar muka pemakai juga berfungsi untuk menginputkan pengetahuan baru kedalam basis pengetahuan sistem pakar, menampilkan fasllitas penjelasan sistem dan memberikan tuntunan penggunaan sistem secara menyeluruh langkah demi langkah sehingga pemakai mengerti apa yang harus dilakukan terhadap sistem.

Syarat utama membangun antar muka pemakai adalah kemudahan dalam menjalankan sistem. Semua

Gambar 1. Konsep dasar fungsi Sistem Pakar berbasis Pengetahuan

\subsection{Konsep umum Sistem Pakar}

Pengetahuan yang dimiliki sistem pakar direpresentasikan dalam beberapa cara. Salah satu 2.3 Backward Chaining (Runut Balik)

metode yang paling umum digunakan adalah tipe rules Runut balik (Backward Chaining) merupakan strategi menggunakan format IF THEN. Banyak sistem pakar pencarian yang arahnya kebalikan dari runut maju yang, dibangun dengan mengekspresikan pengetahuan (Forward Chaning). Proses pencarian dimulai dari dalam bentuk rules. Bahkan, pendekatan berbasis tujuan, yaitu kesimpulan yang menjadi solusi pengetahuan (knowledge-based approach) untuk permasalahan yang dihadapi. Mesin inferensi mencari membangun sistem pakar telah mematahkan kaidah kaidah dalam basis pengetahuan yang pendekatan awal yang digunakan pada sekitar tahun kesimpulannya merupakan solusi yang ingin dicapai, 1950-an dan 1960-an yang menggunakan teknik kemudian dari kaidah kaidah yang diperoleh, masingpenalaran (reasoning) yang tidak mengandalkan masing kesimpulan dirunut balik jalur yang mengarah pengetahuan.

ke kesimpulan tersebut.

Pengetahuan tidak tertulis yang dimiliki oleh seorang Jika informasi-informasi atau nilai dari atribut-atribut pakar harus diekstrasikan melalui wawancara secara yang mengarah ke kesimpulan tersebut sesuai dengan ekstensif oleh knowledge engineer. Proses data yang diberikan maka kesimpulan tersebut pengembangan sistem pakar yang berhubungan dengan merupakan solusi yang dicari, jika tidak sesuai maka perolehan pengetahuan dari pakar maupun sumber lain kesimpulan tersebut bukan merupakan solusi yang dan kodingnya disebut sebagai knowledge engineering. dicari. Runut balik memulai proses pencarian dengan Tahapan pengembangan sistem pakar secara umum suatu tujuan sehingga strategi ini disebut juga goalterlihat pada Gambar 2 di bawah Ini.

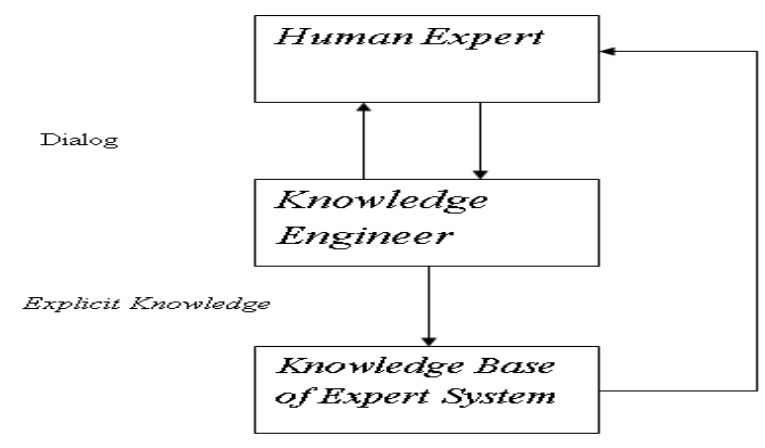

Gambar 2. Pengembangan Sistem Pakar

\subsection{Arsitektur Sistem Pakar}

Adapun arsitektur Sistem Pakar terlihat pada gambar 3.

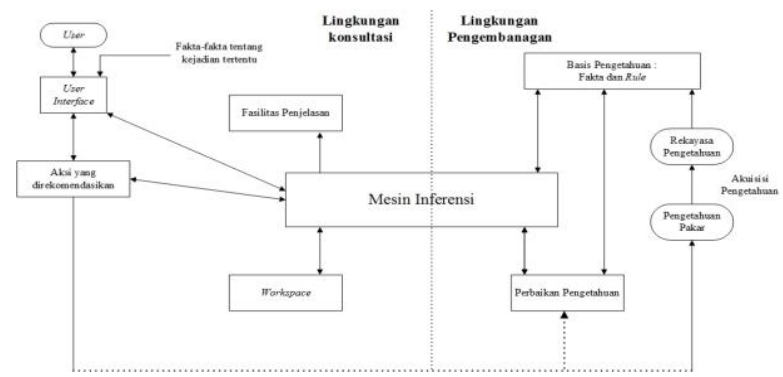

Gambar 3. Arsitektur Sistem Pakar driven.

Ciri- ciri dari Backward Chaining yaitu Menggunakan pendekatan goal-driven, dimulai dari harapan apa yang akan terjadi (hipotesis) dan kemudian mencari bukti yang mendukung (atau berlawanan) dengan harapan kita. Sering hal ini memerlukan perumusan dan pengujian hipotesis sementara. Pada metode inferensi dengan backward chaining akan mencari aturan atau rule yang memiliki konsekuen (Then klausa .) yang mengarah kepada tujuan yang di skenariokan / di inginkan. Gambar 4 dibawah ini adalah diagram Backward Chaining / Runut Balik.

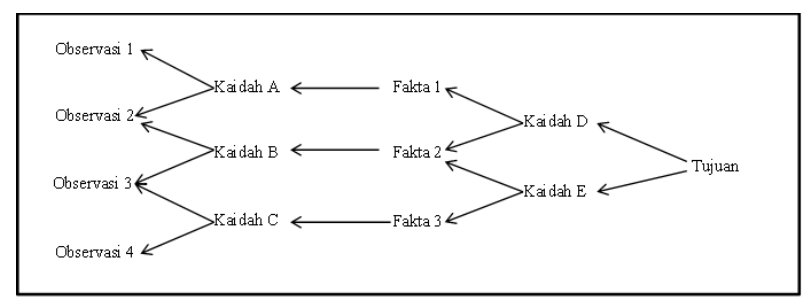

Gambar 4. Diagram Backward Chaining / Runut Balik

\subsection{Langkah-langkah Kerja Backward Chaining}

Langkah-langkah kerja Backward Chaining berisi tahapan-tahapan sistematis yang dilakukan dalam menyelesaikan permasalahan yang akan diteliti dan yang berhubungan dengan metode Backward Chaining.

Jurnal Sistem Informasi dan Teknologi Vol. 1 No. 4 (2019) 42-52 
Adapun Langkah-langkah kerja Backward Chaining metode yang digunakan oleh peneliti adalah metode dapat dilihat pada Gambar 5.

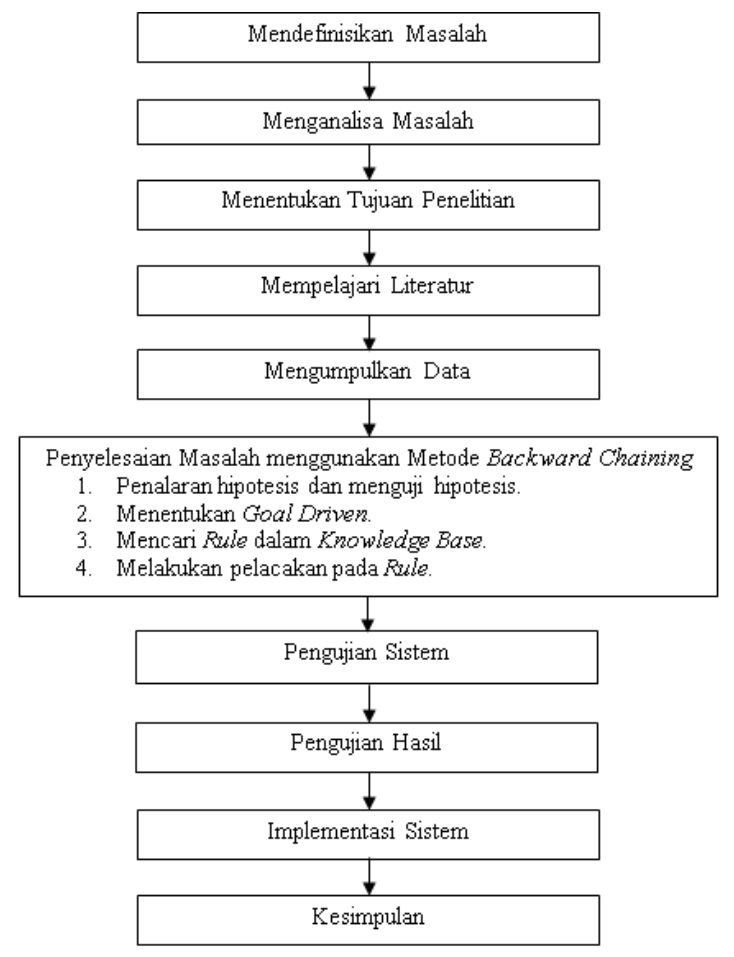

Gambar 5. Langkah-langkah Kerja Backward Chaining

Berdasarkan gambar diatas maka dapat dijelaskan langkah-langkah yang dilakukan adalah:

\section{Mengidentifikasi Masalah}

Tahap identifikasi masalah merupakan langkah awal dalam melakukan suatu penelitian. Pada tahap ini peneliti mendefinisikan permasalahan dengan cara merumuskan untuk mengenalisa lebih jelas masalah yang akan diselesaikan melalui penelitian.

\section{Menganalisa Masalah}

Pada tahap ini peneliti memahami permasalahan dengan ruang lingkup dan batasan yang sudah ditentukan. Dengan menganalisa permasalahan yang ada diharapkan masalah tersebut lebih mudah untuk dipahami.

\section{Menentukan Tujuan Penelitian}

Setelah dilakukan perumusan permasalahan, maka langkah selanjutnya adalah menetapkan tujuan penelitian. Tahap ini diperlukan agar penyusunan dalam penelitian ini tidak menyimpang dari tujuan awal sehingga mendapat hasil yang optimal.

\section{Mempelajari Literatur}

Tahap ini bertujuan untuk memahami metode dan mencari referensi yang mendukung dalam pembuatan sistem pengambilan keputusan ini ataupun sebagai dasar ilmu pengetahuan. Literatur yang digunakan dalam membahas terkait dengan penelitian maupun

Backward Chaining.

\section{Mengumpulkan Data}

Tahapan mengumpulkan data merupakan tahap pengumpulan informasi-informasi yang diperlukan pada penelitian ini. Beberapa cara pengumpulan data yang digunakan dalam penelitian ini sebagai berikut:

a. Observasi atau melakukan pengamatan langsung ke lokasi untuk melihat langsung kegiatan-kegiatan yang dilakukan serta mengumpulkan data-data yang dibutuhkan dalam penelitian.

b. Wawancara atau tanya jawab dengan pihak-pihak terkait dengan penelitian sebagai salah satu sarana yang dilakukan dalam bertukar informasi serta ide-ide.

\section{Masalah menggunakan Metode Backward Chaining}

Tahapan selanjutnya yang dilakukan setelah pengumpulan data selesai adalah melakukan penyelesaian masalah menggunakan metode Backward Chaining. Adapun langkah-langkah yang dilakukan adalah sebagai berikut:

\section{a. Penalaran hipotesis dan menguji hipotesis}

Penalaran dimulai dari hipotesis terlebih dahulu, dan untuk menguji kebenaran hipotesis tersebut harus dicari fakta-fakta yang ada dalam basis pengetahuan.

\section{b. Menentukan Goal Driven}

Pendekatan ini dimulai dengan kesimpulan yang diinginkan dan bekerja secara mundur untuk menemukan fakta-fakta yang mendukung.

c. Mencari Rule dalam Knowledge Base

Penalaran runut balik/Backward Chaining akan mencari aturan-aturan dalam basis data sampai menemukan Then Clause yang cocok dengan tujuan yang diinginkan. Selanjutnya proses pelacakan menggunakan bukti untuk mendukung kesimpulan (premis) untuk aturan tersebut sebagai tujuan baru dan mencari aturan lain dengan tujuan baru sebagai kesimpulannya.

\section{d. Melakukan pelacakan pada Rule}

Melakukan pelacakan hinggan nilai atribut sesuai dengan data pada kesimpulan jika informasi atau nilai dari atribut-atribut yang mengarah ke kesimpulan terebut sesuai dengan data yang diberikan maka kesimpulan tersebut merupakan solusi yang dicari, jika tidak sesuai maka kesimpulan tersebbut bukan merupakan solusi yang dicari.

\section{Pengujian Sistem}

Pada tahap pengujian sistem ini dilakukan untuk memastikan pakah aplikasi Sistem Pakar yang dirancang sudah mencapai tujuan yang diinginkan dan apakah sudah layak di implementasikan kepada user.

\section{Pengujian Hasil}


Pengujian hasil dilakukan agar hasil proses yang ahli dibidang diabetes di RSUD Kabpuaten Solok dilakukan dengan bantuan aplikasi sesuai dengan hasil Selatan.

proses yang dilakukan secara manual sehingga pada tahapan ini dilakukan perbandingan antara hasil perhitungan manual dengan hasil dari perhitungan metode Backward Chaining dengan bantuan aplikasi yang menggunakan bahasa pemograman PHP dan Database MySQL.

\section{Implementasi Sistem}

Setelah pengujian sistem dan pengujian hasil telah Berikut data yang diambil dari penelitian adalah data dilakukan maka langkah selanjutnya adalah rekam medik pasien untuk konsultasi penyakit diabetes implementasi sistem yang bertujuan untuk melihat dapat diliat pada Tabel 1.

kehandalan sebuah sistem, apakah sistem yang dibuat sudah sesuai dengan ketentuan yang telah ada dan sesuai dengan keinginan yang diharapkan.

\section{Kesimpulan}

Pada tahap ini diambil kesimpulan mengenai apa yang sudah dilakukan dan dicapai selama penelitian berlangsung.

\section{Hasil dan Pembahasan}

tahapan analisa dan perancangan mengikuti alur dan aturan guna mempermudah dalam analisa dan perancangan untuk sistem pakar. Adapun tahapan Analisa dan Perancangan ada pada Gambar 6.

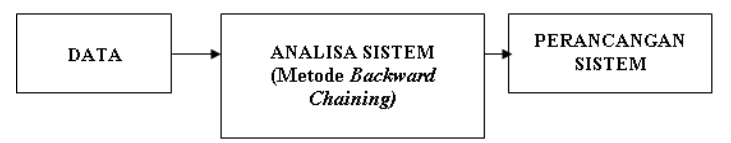

Gambar 6. Tahapan Analisa dan Perancangan

Pada Gambar 6 hal pertama yang perlu dilakakukan adalah menyiapkan data-data yang telah dikumpulkan untuk kemudian dianalisa berdasarkan data yang telah dikelompokkan. Dimana pada penelitian ini data yang digunakan adalah data RM (Rekam Medik) pasien diabetes di RSUD Kabupaten Solok Selatan pada tahun 2019, Selanjutnya pada analisa sistem menjelaskan terkait masalah yang diteliti dan kemudian memecahkan masalah tersebut menggunakan metode Backward Chaining dengan mengubah parameterparameter fungsi jaringan sehingga diperoleh paramater jaringan yang mampu mengoptimalkan kerja jaringan. Setelah itu lakukan perancangan terhadap sistem yang digunakan untuk mendapatkan hasil diagnosis dari sistem pakar.

\subsection{Data}

Berdasarkan pada data yang telah diperoleh pada tahap pengumpulan data yang telah diperoleh pada tahap pengumpulan data, maka selanjutnya akan dilakukan tahap pelatihan dan pengujian data. Sumber data pada penelitian ini yaitu 3 sampel pasien penderita diabetes pada tahun 2019. Data dipreroleh dengan meminta data RM pasien diabetes di RSUD Kabpuaten Solok Selatan selama tahun 2019 dan wawancara dengan dokter yang
Kebutuhan data dalam sistem pakar ini yaitu dengan mengumpulkan data mengenai sistem pakar yang akan dibuat yaitu sistem pakar diabetes, dengan cara wawancara dengan seorang pakar, membaca buku, artikel, internet dan lain-lain yang diperlukan seperti penyakit diabetes, gejala diabetes, pencegahan diabetes dan solusinya.

Tabel 1. Data Pasien

\begin{tabular}{|c|c|c|c|}
\hline Nama & $\begin{array}{l}\text { Umur } \\
\text { (Tahun) }\end{array}$ & Gejala & Diagnosis \\
\hline Tn. A & 51 & $\begin{array}{l}\text { - Letih } \\
\text { - Jemari Kebas } \\
\text { - Gatal-Gatal } \\
\text { - Pusing } \\
\text { - Nyeri Kepala } \\
\text { - Nyeri Punggung }\end{array}$ & $\begin{array}{l}\text { Diabetes Melitus } \\
\text { Tipe } 2\end{array}$ \\
\hline Ny. A & 45 & $\begin{array}{l}\text { - Letih } \\
\text { - Jemari Kebas } \\
\text { - Tumit Nyeri } \\
\text { - Sering Buang Air } \\
\text { Kecil pada Malam Hari } \\
\text { - Berat Badan Turun } \\
\text { - Nyeri Ulu Hati } \\
\text { - Nyeri Kepala } \\
\text { - Pusing }\end{array}$ & $\begin{array}{l}\text { Diabetes Melitus } \\
\text { Tipe } 2\end{array}$ \\
\hline Tn. B & 44 & $\begin{array}{l}\text { - Letih } \\
\text { - Jemari Kebas } \\
\text { - Gatal-Gatal } \\
\text { - Tumit Nyeri } \\
\text { - Pusing } \\
\text { - Kepala Terasa Nyeri } \\
\text { - Perut Terasa Nyeri } \\
\text { - Nyeri Perut Menyesak } \\
\text { ke Ulu Hati }\end{array}$ & $\begin{array}{l}\text { Diabetes Melitus } \\
\text { Tipe } 2\end{array}$ \\
\hline Ny. B & 54 & $\begin{array}{l}\text { - Letih } \\
\text { - Jemari Kebas } \\
\text { - Gatal-Gatal } \\
\text { - Pusing } \\
\text { - Sering Buang Air } \\
\text { Kecil pada Malam Hari } \\
\text { - Nyeri Perut }\end{array}$ & $\begin{array}{l}\text { Diabetes Melitus } \\
\text { Tipe } 2\end{array}$ \\
\hline Ny. C & 57 & $\begin{array}{l}\text { - Letih } \\
\text { - Jemari Kebas } \\
\text { - Gatal-Gatal } \\
\text { - Badan Terasa Gatal } \\
\text { - Pusing } \\
\text { - Penglihatan Kabur }\end{array}$ & $\begin{array}{l}\text { Diabetes Melitus } \\
\text { Tipe } 2\end{array}$ \\
\hline Tn. C & 21 & $\begin{array}{l}\text { - Letih } \\
\text { - Buang Air Kecil pada } \\
\text { Malam Hari } \\
\text { - Jemari Kebas } \\
\text { - Pusing } \\
\text { - Sesak Nafas }\end{array}$ & $\begin{array}{l}\text { Diabetes Melitus } \\
\text { Tipe } 1\end{array}$ \\
\hline Ny. D & 17 & $\begin{array}{l}\text { - Letih } \\
\text { - Jemari Kebas } \\
\text { - Nyeri Kepala } \\
\text { - Buang Air Kecil pada } \\
\text { Malam Hari } \\
\text { - Sering Merasa Haus } \\
\text { - Pusing }\end{array}$ & $\begin{array}{l}\text { Diabetes Melitus } \\
\text { Tipe } 1\end{array}$ \\
\hline
\end{tabular}


Tabel 1. Data Pasien (lanjutan)

Tabel 2. Jenis Penyakit

\begin{tabular}{|c|c|c|c|}
\hline Nama & $\begin{array}{l}\text { Umur } \\
\text { (Tahun) }\end{array}$ & Gejala & Diagnosis \\
\hline Tn. D & 24 & $\begin{array}{l}\text { - Letih } \\
\text { - Jemari Kebas } \\
\text { - Gatal-Gatal } \\
\text { - Sesak Nafas } \\
\text { - Nyeri Perut Menyesak } \\
\text { ke Ulu Hati } \\
\text { - Pusing }\end{array}$ & $\begin{array}{l}\text { Diabetes Melitus } \\
\text { Tipe } 1\end{array}$ \\
\hline Tn. E & 24 & $\begin{array}{l}\text { - Sesak Nafas } \\
\text { - Letih } \\
\text { - Jemari Kebas } \\
\text { - Gatal-Gatal } \\
\text { - Pusing } \\
\text { - Sering Buang Air } \\
\text { Kecil pada Malam Hari } \\
\text { - Berat Badan Turun } \\
\text { - Sering Merasa Haus }\end{array}$ & $\begin{array}{l}\text { Diabetes Melitus } \\
\text { Tipe } 1\end{array}$ \\
\hline Tn. F & 19 & $\begin{array}{l}\text { - Berat Badan Turun } \\
\text { - Sering Buang Air } \\
\text { Kecil pada Malam Hari } \\
\text { - Letih } \\
\text { - Pusing } \\
\text { - Jemari Kebas }\end{array}$ & $\begin{array}{l}\text { Diabetes Melitus } \\
\text { Tipe } 1\end{array}$ \\
\hline
\end{tabular}

\subsection{Analisa Sistem Backwad Chaining}

Berikut Flowchart sistem proses sistem pakar dengan metode Backward Chaining yang dijelaskan pada Gambar 6.

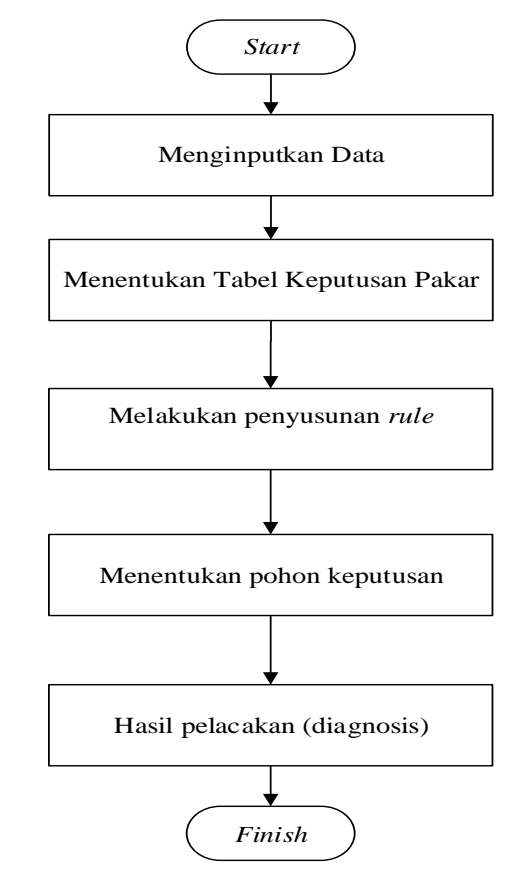

Gambar 6. Tahapan Analisa dan Perancangan

\begin{tabular}{ll}
\hline Kode & \multicolumn{1}{c}{ Jenis Penyakit } \\
\hline P001 & Diabetes Melitus tipe 1 \\
P002 & Diabetes Melitus tipe 2 \\
\hline
\end{tabular}

Pada Tabel 2 terdapat 2 jenis penyakit diberikan kode penyakit seperti P1 untuk Diabetes Melitus tipe 1 dan P2 untuk Diabetes Melitus tipe 2. Hal ini dilakukan untuk menginputkan ke dalam database penyakit nantinya. Berdasarkan Tabel 2 diatas disebabkan oleh beberapa gejala yang akan dijelaskan pada Tabel 3 .

Tabel 3. Jenis Gejala

\begin{tabular}{ll}
\hline Kode Gejala & \multicolumn{1}{c}{ Gejala } \\
\hline G001 & Jemari Kebas \\
G002 & Letih \\
G003 & Pusing \\
G004 & Gatal-Gatal \\
G005 & Nyeri Kepala \\
G006 & Sering Buang Air Kecil pada Malam Hari \\
G007 & Tumit Nyeri \\
G008 & Badan Terasa Gatal \\
G009 & Berat Badan Turun / Naik \\
G010 & Kepala Terasa Nyeri \\
G011 & Nyeri Perut \\
G012 & Nyeri Perut Menyesak ke Ulu Hati \\
G013 & Nyeri Punggung \\
G014 & Nyeri Ulu Hati \\
G015 & Penglihatan Kabur \\
G016 & Perut Terasa Nyeri \\
G017 & Sering merasa haus (polidipsia). \\
G018 & Sering Merasa Lapar (Polifagia) Tetapi Berat \\
G020 & Badan Turun Tanpa Sebab. \\
G021 & Mulut Kering. \\
G022 & Luka di tubuh yang Sulit Sembuh. \\
G023 & Pandangan Kabur. \\
\end{tabular}

Berdasarkan pada tabel 3 setiap gejala akan diberikan kode gejala seperti G001 Jemari Kebas, G002 Letih, G003 pusing dan seterusnya sampai G022 Pandangan kabur dimana kode G001 adalah gejala 1. Pengkodean gejala ini dilakukan untuk mempermudah penginputan data ke dalam database. Berdasarkan tabel diatas akan dicari kesesuaian dengan gejala suatu penyakit tertentu yang ada dalam knowledge-based.

Dari data atau pengetahuan yang didapatkan berupa gejala dan penyakit Diabetes Melitus maka dapat disusun sebuah tabel antara gejala, penyakit, solusi, dan digabungkan dengan pengetahuan dari dokter pakar dalam mendiagnosa penyakit Diabetes Melitus maka akan didapatkan sebuah tabel relasi antara gejala, penyakit dan solusi. Adapun tabel relasi gejala, penyakit dan solusi dapat dilihat pada Tabel 4.

\subsection{Menyiapkan Data Input}

Data yang diambil untuk penelitian ini adalah data penyakit diabetes. Data yang didapat ada 2 jenis penyakit terbesar di RSUD Solok Selatan. Berikut data penyakit yang dapat dilihat pada Tabel 2 .

Jurnal Sistem Informasi dan Teknologi Vol . 1 No. 4 (2019) 42-52 


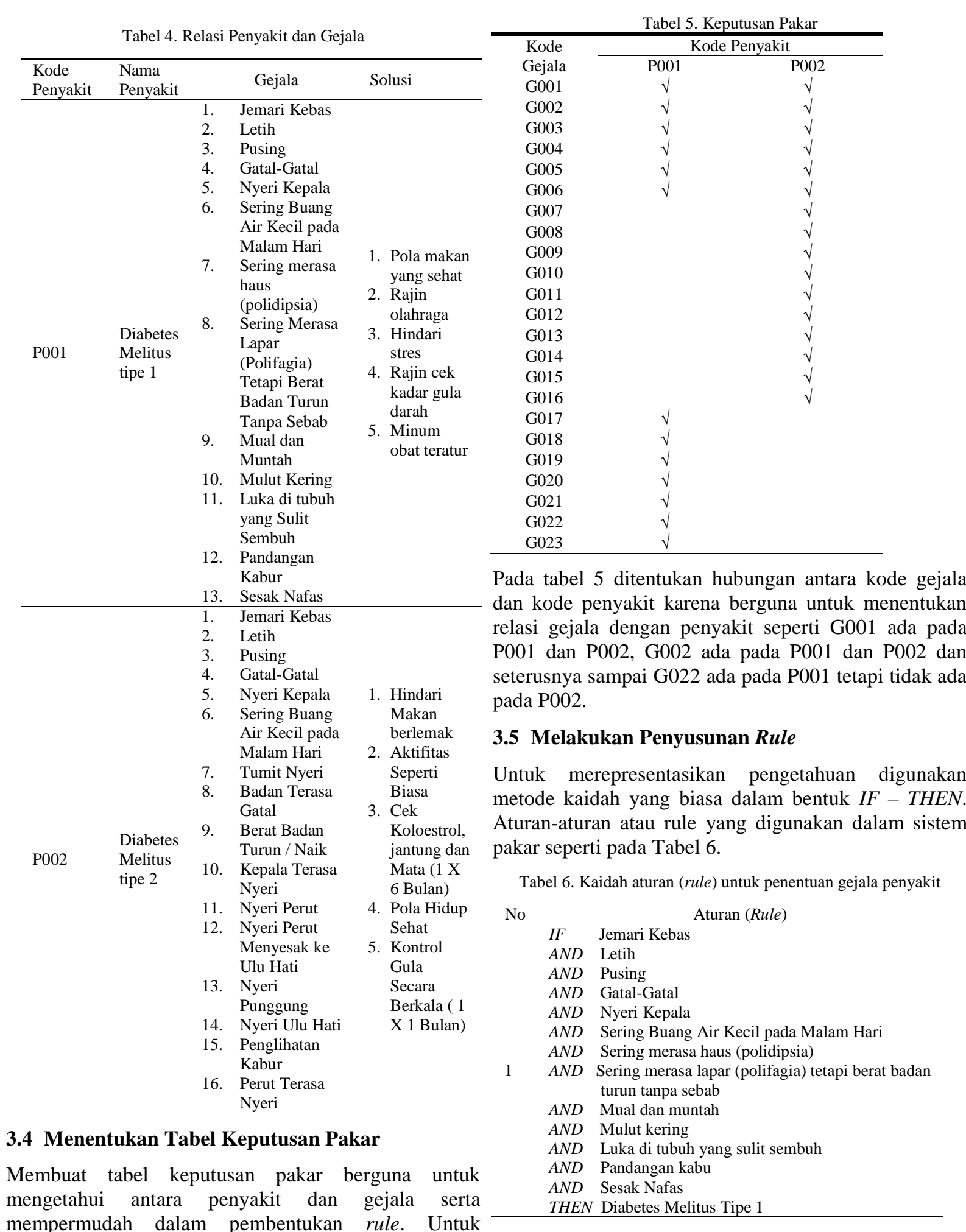
jelasnya akan di tampilkan pada Tabel 5 . 
Tabel 6. Kaidah aturan (rule) untuk penentuan gejala penyakit (lanjutan)

\begin{tabular}{|c|c|c|}
\hline No & & Aturan (Rule) \\
\hline \multirow{17}{*}{2} & $I F$ & Jemari Kebas \\
\hline & $A N D$ & Letih \\
\hline & $A N D$ & Pusing \\
\hline & $A N D$ & Gatal-Gatal \\
\hline & $A N D$ & Nyeri Kepala \\
\hline & $A N D$ & Sering Buang Air Kecil pada Malam Hari \\
\hline & $A N D$ & Tumit Nyeri \\
\hline & $A N D$ & Badan Terasa Gatal \\
\hline & $A N D$ & Berat Badan Turun / Naik \\
\hline & $A N D$ & Kepala Terasa Nyeri \\
\hline & $A N D$ & Nyeri Perut \\
\hline & $A N D$ & Nyeri Perut Menyesak ke Ulu Hati \\
\hline & $A N D$ & Nyeri Punggung \\
\hline & $A N D$ & Nyeri Ulu Hati \\
\hline & $A N D$ & Penglihatan Kabur \\
\hline & $A N D$ & Perut Terasa Nyeri \\
\hline & THEN & Diabetes Melitus Tipe 2 \\
\hline
\end{tabular}

Pada Tabel 6 jika dituliskan ke dalam kalimat akan menghasilkan sebagai berikut: Untuk no.1 JIKA jemari kebas DAN letih dan Pusing DAN Gatal-Gatal DAN Nyeri Kepala DAN Sering Buang Air Kecil pada Malam Hari DAN Sering merasa haus (polidipsia) DAN Sering merasa lapar (polifagia) tetapi berat badan turun tanpa sebab DAN Mualdan muntah DAN Mulut kering DAN Luka di tubuh yang sulit sembuh DAN Pandangan kabur DAN Sesak Nafas MAKA penyakit yang diderita adalah Diabetes Melitus Tipe 1. Untuk no. 2 JIKA Jemari Kebas DAN Letih DAN Pusing DAN Gatal-Gatal DAN Nyeri Kepala DAN Sering Buang Air Kecil pada Malam Hari DAN Tumit Nyeri DAN Badan Terasa Gatal DAN Berat Badan Turun / Naik DAN Kepala Terasa Nyeri DAN Nyeri Perut DAN Nyeri Perut Menyesak ke Ulu Hati DAN Nyeri Punggung DAN Nyeri Ulu Hati DAN Penglihatan Kabur DAN Perut Terasa Nyeri MAKA penyakit yang diderita adalah Diabetes Melitus Tipe 2.

\subsection{Menentukan Pohon Keputusan}

Berdasarkan aturan pada tabel 6 terlihat faktor yang mempengaruhi hasil mendeteksi penyakit diabetes yang memiliki gejala-gejala tertentu sehinggan dapat dibuat pohon keputusan seperti pada Gambar 7.

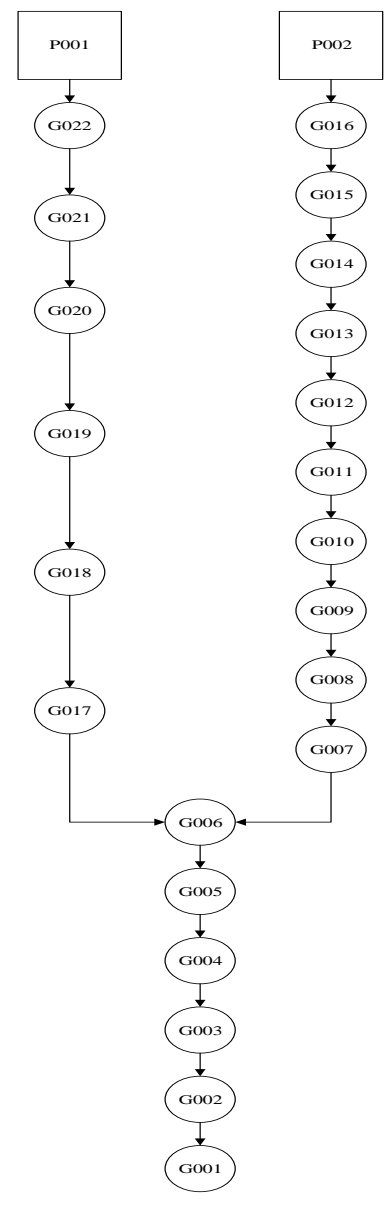

Gambar 7. Pohon Keputusan

Pada Gambar 7 alur yang terjadi pada pohon keputusan adalah alur Backward Chaining dimana untuk mendapatkan hasil / tujuan maka harus dicari ke belakang seperti P001 adalah G022, G021, G020, G019, G018, G017, G006, G005, G004, G003, G002 dan G001 sedangkan untuk P002 adalah G016, G015, G014, G013, G012, G011, G010, G009, G008, G007, G006, G005, G004, G003 G002 dan G001.

\subsection{Hasil Pelacakan didapatkan (Diagnosis)}

Setelah dilakukan proses penyusunan rule, maka berikut adalah tabel hasil penyakit dan gejala pada Tabel 7.

Tabel 7. Hasil proses pelacakan

\begin{tabular}{clc}
\hline No & \multicolumn{1}{c}{ Gejala } & Penyakit \\
\hline \multirow{2}{*}{1} & G001, G002, G003, G004, G005, G006, & \multirow{2}{*}{ P001 } \\
& G017, G018, G019, G020, G021, G022 & \\
\multirow{2}{*}{2} & $\begin{array}{l}\text { G001, G002, G003, G004, G005, G006, } \\
\text { G007, G008, G009, G010, G011, G012, }\end{array}$ & \multirow{2}{*}{ P002 } \\
& G013, G014, G015, G016 & \\
\hline
\end{tabular}

\subsection{Hasil dan Solusi}

Setelah didapatkan hasil proses pelacakan yang dilakukan pada Tabel 7 maka dihasilkan solusi dari gejala-gejala dan penyakit seperti pada Tabel 8. 
Tabel 8. Hasil dan Solusi

Tabel 8. Hasil dan Solusi (lanjutan)

\begin{tabular}{|c|c|c|c|c|c|c|c|c|c|}
\hline $\begin{array}{l}\text { Nama } \\
\text { Pasien }\end{array}$ & $\begin{array}{l}\text { Kode } \\
\text { Gejala }\end{array}$ & Gejala & $\begin{array}{c}\text { Kode } \\
\text { Penyakit }\end{array}$ & $\begin{array}{c}\text { Nama } \\
\text { Penyakit }\end{array}$ & $\begin{array}{l}\text { Nama } \\
\text { Pasien }\end{array}$ & $\begin{array}{l}\text { Kode } \\
\text { Gejala }\end{array}$ & Gejala & $\begin{array}{c}\text { Kode } \\
\text { Penyakit }\end{array}$ & $\begin{array}{c}\text { Nama } \\
\text { Penyakit }\end{array}$ \\
\hline \multirow{6}{*}{ Tn. A } & G002 & Letih & \multirow{6}{*}{ P002 } & \multirow{6}{*}{$\begin{array}{c}\text { Diabetes } \\
\text { Melitus } \\
\text { Tipe } 2\end{array}$} & & G023 & Sesak Nafas & & \multirow{10}{*}{$\begin{array}{c}\text { Diabetes } \\
\text { Melitus } \\
\text { Tipe } 1\end{array}$} \\
\hline & G001 & Jemari Kebas & & & & G002 & Letih & & \\
\hline & G004 & Gatal-Gatal & & & & G001 & Jemari Kebas & & \\
\hline & G003 & Pusing & & & & G004 & Gatal-Gatal & & \\
\hline & G005 & Nyeri Kepala & & & $\mathrm{Tn} F$ & G003 & Pusing & $P 001$ & \\
\hline & G013 & Nyeri Punggung & & & In. $E$ & & Sering Buang Air & PUO1 & \\
\hline \multirow{10}{*}{ Ny. A } & G002 & Letih & \multirow{10}{*}{ P002 } & \multirow{9}{*}{$\begin{array}{c}\text { Diabetes } \\
\text { Melitus } \\
\text { Tipe } 2\end{array}$} & & G006 & Kecil pada Malam & & \\
\hline & G001 & Jemari Kebas & & & & & Hari & & \\
\hline & G007 & Tumit Nyeri & & & & G009 & Berat Badan Turun & & \\
\hline & & Sering Buang Air & & & & G017 & Sering Merasa Haus & & \\
\hline & G006 & $\begin{array}{l}\text { Kecil pada Malam } \\
\text { Hari }\end{array}$ & & & \multirow{6}{*}{ Tn. F } & G009 & $\begin{array}{l}\text { Berat Badan Turun } \\
\text { Sering Buang Air }\end{array}$ & \multirow{6}{*}{ P001 } & \multirow{6}{*}{$\begin{array}{c}\text { Diabetes } \\
\text { Melitus } \\
\text { Tipe } 1\end{array}$} \\
\hline & G009 & Berat Badan Turun & & & & G006 & Kecil pada Malam & & \\
\hline & G014 & Nyeri Ulu Hati & & & & & Hari & & \\
\hline & G005 & Nyeri Kepala & & & & G002 & Letih & & \\
\hline & G003 & Pusing & & & & G003 & Pusing & & \\
\hline & G002 & Letih & & & & G001 & Jemari Kebas & & \\
\hline
\end{tabular}

Dari Tabel 8 diatas bisa disimpulkan bahwa hubungan

emari Kebas

G007 Gutal-Gatal

Tn. B G003 Pusing

G010 Kepala Terasa Nyeri

G016 Perut Terasa Nyeri

Nyeri Perut

G012 Menyesak ke Ulu

Hati

G002 Letih

G001 Jemari Kebas

G004 Gatal-Gatal

Ny. B G003 Pusing

G006 Sering Buang Air

Kecil pada Malam

Hari

G011 Nyeri Perut

G002 Letih

G001 Jemari Kebas

Ny. C G004 Gatal-Gatal

G008 Badan Terasa Gatal

$\mathrm{P} 002$

Diabetes

G003 Pusing

G015 Penglihatan Kabur

G002 Letih

G006 Buang Air Kecil

Tn. C G006 pada Malam Hari

G001 Jemari Kebas

G003 Pusing

G023 Sesak Nafas

G002 Letih

G001 Jemari Kebas

G005 Nyeri Kepala

P002

antara kode penyakit dengan penyakit juga sesuai. Pada

Tipe 2 kolom solusi akan menampilkan solusi apa yang haris dilakukan pengguna saat mengetahui ada penyakit di dalam tubuh pengguna, setiap penyakit mempunyai solusi yang berbeda tergantung dari hasil penyakit dari konsultasi yang dilakukan pengguna.

Diabetes

P002 Melitus

Tipe 2

\section{Kesimpulan}

Pada sistem pakar diagnosa Diabetes Melitus ini terdapat 2 jenis penyakit yang memiliki total 23 gejala. Solusi diberikan sebagai langkah awal dalam menangani penyakit secara dini dan bisa dilakukan dirumah. Sehingga dapat digunakan untuk membantu

Tipe 2 masyarakat untuk mengenali atau mendiagnosa awal Diabetes Melitus secara dini. Diharapkan aplikasi ini selain membantu mendiagnosa penyakit Diabetes Melitus, juga di harapkan dapat dapat memberikan Melitus informasi dan edukasi kepada masyarakat luas secara Tipe 1 umum.

\section{Daftar Rujukan}

\begin{tabular}{|c|c|c|c|c|}
\hline \multirow{3}{*}{ Ny. D } & G005 & Nyeri Kepala & \multirow{4}{*}{ P001 } & \multirow{4}{*}{$\begin{array}{c}\text { Diabetes } \\
\text { Melitus } \\
\text { Tipe } 1\end{array}$} \\
\hline & G006 & $\begin{array}{l}\text { Buang Air Kecil } \\
\text { pada Malam Hari }\end{array}$ & & \\
\hline & G017 & Sering Merasa Haus & & \\
\hline & G003 & Pusing & & \\
\hline \multirow{8}{*}{ Tn. D } & G002 & Letih & \multirow{8}{*}{ P001 } & \multirow{8}{*}{$\begin{array}{c}\text { Diabetes } \\
\text { Melitus } \\
\text { Tipe } 1\end{array}$} \\
\hline & G001 & Jemari Kebas & & \\
\hline & G004 & Gatal-Gatal & & \\
\hline & G023 & Sesak Nafas & & \\
\hline & \multirow{3}{*}{ G012 } & Nyeri Perut & & \\
\hline & & Menyesak ke Ulu & & \\
\hline & & Hati & & \\
\hline & G003 & Pusing & & \\
\hline
\end{tabular}

[1] Yuvidarmayunata, Y. (2018). Sistem Pakar Berbasis Web Menggunakan Metode Backward Chaining untuk Menentukan Nutrisi yang Tepat bagi Ibu Hamil, INTECOMS: Journal of Information Technology and Computer Science, 1(2), pp. 231239. https://doi.org/10.31539/intecoms.v1i2.302

[2] Julita, R. (2018). Sistem Pakar Pemilihan Menu Makanan Berdasarkan Penyakit Dan Golongan Darah. Pseudocode, 5(1), 56-67. https://doi.org/10.33369/pseudocode.5.1.56\%20-\%2067

[3] Latubessy, A., \& Jazuli, A. (2017). Analisis Model Penelusuran Backward Chaining dalam Mendeteksi Tingkat Kecanduan Game pada Anak. Jurnal Teknologi dan Sistem Komputer, 5(4), 129-134. https://doi.org/10.14710/jtsiskom.5.4.2017.129-134

[4] Lesmana, Sabda, L. (2017). Sistem Pakar Backward Chaining Untuk Pemilihan Alat Kontrasepsi yang Cocok Berbasis Android. Jurnal Edik Informatika Penelitian Bidang Komputer Sains dan Pendidikan Informatika, 4(1), 10-22. https://doi.org/10.22202/ei.2017.v4i1.2533

[5] Fadel A., Mardayulis M., \& Yunita P. (2019). Aplikasi Sistem Pakar Pusat Informasi Konseling Remaja (Pik-R) di SMAN 2

Jurnal Sistem Informasi dan Teknologi Vol . 1 No. 4 (2019) 42-52 
Dumai dengan Metode Backward Chaining Menggunakan Bahasa Pemograman PHP. INFORMATIKA, 10(2), 47-55.

[6] Al-Hajji, A., Fatimah, A., AlSuhaibani, M., \& Nouf, S. AlHarbi (2019). Online Knowledge-Based Expert System (KBES) For Psychological Diseases Diagnosis. 6th International Conference on Computer Science and Information Technology, 57-71. doi: $10.5121 /$ csit.2019.90206 